\title{
A New Floor for the Silenced? Congolese Hip-Hop in Belgium
}

Contrary to most other former metropoles, Belgian postcolonial memory does not provoke much turmoil. It is dominated by white narratives, which highlight Congolese gratitude and nostalgia. This article questions this discourse by analyzing hip-hop songs of Congolese artists in Belgium. Many songs deal with the urban context, but the colonial past has recently also become a major topic. Hip-hop songs give voice to hybridity and frustration, criticizing both Belgians and Congolese. Simultaneously, they reveal a great deal of ignorance among Congolese immigrants about their country's history, for which both Congolese parents and Belgian society are blamed. All in all, hip-hop artists denounce the neglect of the Congolese voice in postcolonial memory. 


\section{INTRODUCTION}

In most of the former colonial metropoles, postcolonial memory causes much debate. In almost every year of the last decade, at least one new memorial has been inaugurated in the Netherlands, subsequently occupying a place in postcolonial narratives. In France, a guerre de mémoires (war of memories) broke out in 2005 after the Union for a Popular Movement (UMP), the center-right party of Jacques Chirac and Nicolas Sarkozy, voted for a law stating that education programs should also highlight the positive role of the French colonial empire. Several anniversaries ended in heated discussions, such as in 1992, when Spain commemorated the discovery of America in 1492; in 1998, when Portugal marked Vasco da Gama's landing in India in 1498; in 1998, when France commemorated the 200th anniversary of the abolition of slavery; in 2002, when the Netherlands officially remembered the founding of the East India Company in 1602; and in 2007, when Great Britain marked the bicentenary of the ban on the slave trade in 1807 (Bancel et al. 2010; Bertrand 2006; Oostindie 2010).

Belgium recently also commemorated a number of major anniversaries related to its colonial history. The year 2008 was the centenary of the transformation of the Congo Free State-King Leopold II's private fiefdom-to the Belgian Congo, a regular colony run by the Belgian state. The following year was a minor year of commemoration, marking the 100th anniversary of King Leopold's death. On the other hand, 2010 was a double anniversary of both the establishment of the Congo Free State in 1885 and the independence of the First Republic of the Congo in 1960.

These anniversaries did not provoke the turmoil that characterized postcolonial celebrations in the neighboring countries. This is remarkable since international scholarship generally assesses Belgium as the poorest pupil in the class of colonial powers. In Congo, Brussels failed to train an intellectual elite, exploited the local economy, segregated the society, and controlled its vast mineral resource- a situation that produced violence (Abernethy 2000, 126, 158; Butlin 2009, 434, 507). During the anniversaries, this negative role was acknowledged, but simultaneously balanced with a positive narrative about infrastructure, primary education, etc. (Goddeeris 2011; Goddeeris and Sindani 2011).

The fact that Belgian memory is far less contested is accounted for by several factors. A first explanation is the fact that debates had 
already raged ten years earlier. In the late 1990s, Belgian society was confronted by two controversial books on the Congo. In 1998, the American author Adam Hochschild accused Leopold II of genocide in his bestseller King Leopold's Ghost (1999). A year later, the Belgian social scientist Ludo de Witte $(1999,2001)$ suggested that Belgian authorities were accessory to the assassination of the Congo's first Prime Minister, Patrice Lumumba, in January 1961. As a result of the controversy, the Belgian Parliament established a commission of inquiry in 2000, which concluded that a number of Belgian government members and other Belgian players bear a moral responsibility in the circumstances that led to Lumumba's death (De Vos et al. 2004). The turn of the century can therefore be regarded as a catharsis in Belgium's dealing with its colonial past. In the following years, the country aspired to regain a postcolonial consensus (Castryck 2006). By 2010 , it seemed to be successful, in spite of international scholarship's criticism (e.g. Goldberg 2009, 170-75), which is largely neglected.

A second explanation is the absence of a unified Belgian identity. The country is facing its most dramatic crisis ever-not in finance, but in politics and identity. The polarization between the Dutch-speaking Flemish in the north against the French-speaking Walloons in the south and Brussels has intensified in recent years. After the federal elections of June 2007, it took 194 days to form a government, forty-six days longer than the previous record of 1988 . The government proved unstable, provoking new elections in June 2010. Enduring political disagreements fuelled by the differences between the northern and the southern parts of country resulted in another 541 days of stop-start negotiations, before a new government was sworn in on 6 December 2011.

The crisis mirrors the treatment of the colonial past. As a matter of fact, there are two different narratives. Francophone citizens largely identify with Belgium and, accordingly, with its former colony. Perceiving criticism of its colonial policy as criticism of Belgium itself, they prefer a positive discourse on colonialism. In 2010, Louis Michel, the former foreign minister (1999-2004) and European commissioner (2004-2009), called Leopold II “a visionary" and "a hero" (quoted in Van Cauwelaert 2010,3). A collective volume on the Congolese independence, produced in the same year by the most authoritative Congo connoisseurs, is completely silent about Belgian involvement in Lumumba's murder. Admitting that the circumstances "were described in various ways, but none of them completely correspond to the truth," 
it denies the parliamentary commission's conclusions (Gérard-Libois et al. 2010, 100).

In Flanders, by contrast, the discourse is dominated by an acclaimed monograph: David Van Reybrouck's Congo: Een geschiedenis (2010). Van Reybrouck is more critical and takes more distance, but is still quite positive about the Belgians' darkest chapters and may therefore be labeled as a Belgian Niall Ferguson, who popularized a conservative reading of the British Empire (Goddeeris and Sindani 2011). Van Reybrouck's book is due to be translated but is hardly known in the French-speaking world, neither in the Congo nor in Wallonia. Given the Belgian identity crisis, the topic of the Congo creates little common discourse between the country's Dutch- and French-speaking inhabitants.

A third explanation for the lack of postcolonial debate relates to the relatively limited postcolonial immigration to Belgium. Only a few dozen of thousands of Congolese live in Belgium, half of whom immigrated after 1990. This is in stark contrast with the situation in the neighboring countries. In the Netherlands, one million of the sixteen million inhabitants can trace their roots to the former Dutch East Indies, either as first generation migrants or through parental lineage. In France and Great Britain, the bulk of the immigrants originate from former colonies. Even in Portugal, there are 150,000 postcolonial immigrants in spite of the fact that decolonization took place in an era when immigration was set back by the oil crisis (Oostindie 2010; Wihtol de Wenden 2010). In all of these neighboring countries, immigrants from the former colonies are the most vocal counter-voices in the postcolonial debate. Their presence not only leads to a shared history and a growth of postcolonial lieux de mémoire (sites of memory) in the metropole, but also creates discussions about postcoloniality.

Strikingly, no Congolese historians or journalists have been translated into Dutch, and the ones who are published in French follow a pro-Belgian narrative. ${ }^{1}$ This does not mean that they are completely silenced. On the contrary, many of the Belgian authors who now write about the Congo have traveled extensively across the country and frequently quote their Congolese interlocutors. However, their opinions are filtered, possibly by self-censorship. As a result, the common narrative is strikingly positive, highlighting gratitude and nostalgia. Stories about the sourire congolais (the Congolese smile) and the noko or oncles belges (Belgian uncles) are emblematic. 
There are, however, independent voices. This article will inquire into the practices of self-identification of Congolese hip-hop artists in Belgium and examine to what extent they subscribe to mainstream narratives. We will examine how Congolese immigrants in Belgium think about the two countries, the Belgian-Congolese relationship, and their own frequently unsettling position in between cultural poles. How do Congolese hip-hop artists relate to the colonial past and the postcolonial present? Which elements are key to their identities, and what is the Belgian reception of their opinions?

In answering these questions, we draw inspiration from the concept of hybridity commonly employed within post-colonial critical studies. In the work of Homi Bhabha (1985), the notion of hybridity is used to articulate the idea that cultural difference is not given, but an effect of power relationships in flux, and involving the stabilization and contestation of authority. Cultural difference is constructed through an "object of otherness" which ensures that cultures are always profoundly ambivalent and thus hybrid phenomena. Bhabha talks about a liminal position or "third space" from which new bases of authority can be established. In the (post-) colonial context, cultural hybridity refers to practices of signification which impinge upon the dominant discourse and thereby transforms it into a marker of difference. In the concluding section of this article, the framework developed by Bhabha will help shed light on the tensions that exist between the mainstream narratives and the performances of the Congolese hip-hoppers, but also within the Brussels's subculture itself.

\section{CONGOLESE IMMIGRANTS AND HIP-HOP ARTISTS IN BELGIUM}

According to official statistics, as of 1 January 2006, 40,301 Congolese lived in Belgium. From an international perspective, this is a small number, but within a Belgian context, this number has recently grown significantly. Fifteen years earlier, as of 1 January 1991, the authorities recorded only 17,451 Congolese. Congolese immigration has increased substantially from the 1990s onwards. The difference between the 1991 and 2006 statistic is larger than they first appear because naturalized Belgians are not included in the 2006 figures (Schoonvaere n.d., 12, 16, 21). However, these figures also reveal that prior to the 1990s, Congolese immigration was negligible. 
As a matter of fact, one can hardly speak of a Congolese migration during those first decades after Congolese independence. Arrivals were highly individualized, and migration currents or waves were absent (Kagne 2008). Congolese were not hired to compensate the lack of labor forces in Belgium, and the events of 1960 were not followed by an extensive immigration of black Congolese to the metropole. ${ }^{2}$ The Congolese in Belgium were not even regarded as immigrants since most of them were supposed to stay only temporarily in the country (Etambala 1993,2; cf. Tipo-Tipo 1995; Nyatanyi 1007,33). The largest groups consisted of students, diplomats, and businessmen. In addition, there were also a number of opponents to the Mobutu regime who received political asylum. Growing in number in the 1980s, their settlement was unaffected by the cessation of Belgian migration of 1974.

The early 1990s constituted the major watershed. Mobutu's democratization process, along with the looting and plundering episodes in September 1991 and January 1993, were turning points. More and more Congolese refugees began to flee to Belgium. This political emigration was further incited by the war with Rwanda from 1996 onwards, Laurent-Désiré Kabila's march to Kinshasa in 1997, and the war with the militia allied to Rwanda and Uganda from 1998 onwards. Since the 2000s, family reunion became a migration factor as important as political asylum.

During the last years, the Congolese in Belgium, and particularly in Brussels, have accordingly developed into a flowering community, characterized by various cultural life worlds that are especially manifest around bodily practices. As the Belgian anthropologist and specialist of Congolese migration Bambi Ceuppens (forthcoming) argued, "Young Congolese vent their aspirations and frustrations through bodily practices such as dance, photography, music making, sport and theatre." Regarding music, several styles are particular to Congolese migrants, including religious songs in Pentecostal churches, rumba, and hip-hop. The latter, a favorite means of musical expression for the offspring of marginalized immigrants in Western countries, is indeed widely popular among Congolese.

From the 2000s onwards, Congolese in Brussels began composing hip-hop songs. By doing so, they caught up with a subculture that originated in the 1970s in the Bronx, a borough in New York City mainly inhabited by black Americans. It is closely related with rap music but covers a whole lifestyle including breakdance, graffiti, 
DJs, etc. The genre consists of rhythmic and electronic bass music and rhyming lyrics. Following King Grandmaster Flash's album The Message (1982), the texts often contain social criticism. Hip-hop has widely been neglected by the political and social elite, who turn a blind eye to the subculture given its negative image of violence, drugs, social backwardness, and misogyny. This portrayal has been challenged in academia. Already in the 1990s, a number of scholars, such as Tricia Rose (1994, 2008) and the French social scientist Laurent Mucchielli (1999), have pointed out the high potential of the hip-hop scene as a research object. In the following decade, an increasing number of studies appeared on the subject, also on hip-hop scenes outside of the US. Many studies focus on particular European countries, but others give broader overviews or elaborate on specific issues (e.g., Loh and Verlan 2000, 2006; Mitchell 2001; Durand 2002; Maxwell 2003; Basu and Lemelle 2006; Terkourafi 2010). Neither Belgium as a scene nor the Congolese as actors have received significant attention, apart from a handful of master theses (e.g., Vanmarsenille 2001; Vanden Broucke 2006), articles in popular press (e.g., Tilkin 2011; Corin and Vankersschaever 2012), and introductory chapters (e.g., Beau 1996; Lapiower 1997; Kuppens 2008).

This lack of attention is partly explained by the limited popularity of hip-hop in Belgium, certainly in comparison with the neighboring countries, but also has to do with the division of the Belgian hiphop scene into a Dutch- and a French-speaking part. In Flanders, a number of singers have popularized the style, many of them using dialects (Ceuppens, forthcoming). In the French-speaking part, hiphop is dominated by immigrants who seldom reach the charts (Beau 1996, 129; Lapiower 1997, 18). The exception is Stromae, a singer of Belgian-Rwandan origin who became famous across Europe with a number one hit "Alors On Danse" in the summer of 2010. Not surprisingly, there is a considerable influence from France, although this study will not only examine similarities, but also the important differences between the French hip-hop scene and Congolese hiphoppers in Belgium.

The Belgian Congolese hip-hop scene is mainly French-speaking and concentrated in Brussels. This is not surprising since almost half of the Congolese immigrants between 2001 and 2005 settled in the Belgian capital. Even hip-hop artists in other cities feel connected to Brussels. Abou Mehdi, who settled in Charleking City (Charleroi) and established the hip-hop collective Nomade-Hür, sings about 
"BXL City," the nickname of Brussels (Mehdi and Saladin 2009; Mehdi 2011a). It is a real subculture, which rarely collaborates with Belgian hip-hop artists, sometimes even as a deliberate strategy that allows the uncensored ventilation of criticism.

There are dozens of Congolese hip-hop artists in Belgium. We analyzed the ones who sing about their personal experiences with Belgium and Congo, excluding those artists whose songs largely emulate American or French hip-hop. We looked at the albums of four Congolese hip-hop artists relating to their Congolese roots: Pitcho (Crise de Nègre [2010a]), Baloji (Hotel Impala [2007b] and Kinshasa Succursale [2011]), Gandhi (Le point G - Tome 1: Jeux de maux [2010e]), and 13Hor (Cris du Cour [2010b]). A special project on the occasion of the 50th anniversary of Congolese independence also led to a compilation titled Héritage (Various artists 2010), which featured many artists in the Brussels scene. A number of other artists post their songs and video clips on YouTube. We also contacted a number of these artists and their producers via Facebook and other communication channels, and we met some in person. ${ }^{3}$

\section{THE URBAN CONTEXT}

"La maison merde" (the shit house) was the way Za described Brussels in 2009. The image is emblematic for many Congolese hip-hop songs. Many artists sing about their poor living circumstances. Violence, financial problems, large and anonymous blocks, youth loitering on the street, etc. are recurring themes. "Le concept c'est la rue, le concept c'est l'euro, le concept c'est la violence" (the concept is the street, the euro, the violence), as Dalsim (2010) summarizes. Another exemplary song is "Les Bras Ballant [sic]" (Loose Hands) by Gandhi (2010f). It tells the story of an African boy whose fighting parents are in such financial trouble that Santa Claus will not come that year. "Merde" (Shit) is the only thing Gandhi is able to utter when looking the boy in his eyes. At the end of his song, when the music has gone, he raps, "Nous, on ne sourit plus, ne rit plus, ne prie plus, ne vit plus. Peut être que le destin est prometeur, mais on n'y croit plus. Peut être que l'amour est sous la haine, mais on ne voit plus." (We do not smile anymore, we do not laugh anymore, we do not pray anymore, we do not live anymore. Destiny may be promising, but we do not believe this. Love may be underneath hatred, but we do not see it.) 
Some rappers foster this misery. Dalsim, for instance, performs in a video clip dealing cannabis and carrying a gun. Most others, however, call their audience to break through the vicious circle, often by referring to their own success stories. "Reste ambitieux" (Keep ambitious), as Abou Mehdi (2011a) sings. "Dans le carrefour de ma vie je prends la direction du progrès" (In the crossroads of my life I take the direction towards progress) is a similar message from Romano Daking (2010). Still, they agree that this is not easy given their violent surroundings. Even the Belgian police are represented as hostile. In many clipssuch as the ones of Za, Dalsim, Abou Mehdi, and Gandhi-patrol cars and/or cops are shown. Gandhi (2010c) feels targeted by the police: "Les flics ont nos photos, plus vieilles que l'echographie." (The cops have our pictures, older than echography.) In another song (Gandhi 2010f), he pairs this with the colonial era: "Le coup de matrac nous rappelle à tous qu'on était esclave." (The baton's blow reminds all of us that we were slaves.)

Gandhi does not link this with racism, but fellow singers do. Pitcho (2010f) is already accustomed to the fact that he is judged by his color: "J'ai pris l'habitude qu'il me juge par mon teint." In an interview (Pitcho et al. 2010), he elaborates on the racist inequality: "L'Europe est un ami de longue date, un ami qui sétait pris longtemps pour Tarzan, un ami qui nous a pris longtemps pour Tchitta à cause de nos sourires bananas chiquitas." (Europe has been an old friend, a friend who was taken for Tarzan during a long time, a friend who took us for a long time as Tchitta given our Chiquitta banana smiles.)

It goes without saying that Pitcho's criticism of racism is backed by all of the other hip-hop artists. Moreover, they also criticize the socalled "bounties," people with black skin aspiring to be white inside. Just like Frantz Fanon, who described hybrid colonized subjects as inauthentic in his famous Black Skin, White Masks (1952), they denounce attempts to adopt whiteness, both psychologically and physically. "La dépigmentation de la peau laisse des séquelles" (The decoloration of the skin leaves an after-effect), sings Baloji (2007e). Pitcho (2010b) considers this treason: "Mes sœurs s'éclaircissent le teint, à la recherche d'un élixir certain, pour conjurer le sort au lieu d'avancer ensemble et de conjuguer l'effort." (My sisters make their complexion fairer, in search of a certain elixir, in order to turn away their fate instead of going forward together and combining effort.)

This does not mean that Congolese do not suffer from an identity crisis. On the contrary, they have a feeling of homelessness, of being 
torn between two continents, and of belonging to anywhere and nowhere. Baloji (2007d) expresses this feeling of being in between with a comparison, "Je suis entre deux mondes comme Gibraltar." (I find myself between two worlds, just like Gibraltar [Sioen 2010].) 13Hor (and Kankonda 2010) uses a similar image: "le cul entre deux chaises" (the ass between two chairs). There is no place where he feels at home: "Être qu'un sale nègre quand je suis en Belgique, être qu'un sale Belge sur les terres d'Afrique." (Being a dirty nigger when I am in Belgium, being a dirty Belgian when I am on African ground.) BD Banx (and Massamba 2010) faces the same problem: "Apatride porteur d'aucun drapeau. Suis-je Belge? Suis-je du Congo? Ou juste un Belge noir de peau?" (Stateless bearer of neither flag. Am I Belgian? Am I from the Congo? Or just a Belgian with a black skin?)

Since national identities - the Belgian as well as the Congoleseare closed to these immigrants, hip-hop artists identify with the city and the districts they live in. Many video clips hold images of Brussels. Gandhi's clip for "Les Bras Ballant" has signs of boroughs and subway stations, such as Evere, Madou, Simonis, Rogier, and Porte de Namur. In the clip for "BXL Zoo," Djubay's entourage shows a number of postcodes of Brussels municipalities.

The most iconic Congolese-Brussels song is "Empire State of Brussels" by 13Hor, Daddy K., and Aziza. The song, an adapted cover of the 2009 world hit "Empire State of Mind" by Jay- $Z$ and Alicia Keys, features various elements of city life: street names, city abbreviations (BX), and even popular shops ("Du Foot Locker au Fresh Kicks, du mac do [McDonalds] au snack frère"). Interestingly, it also mentions "le paki," a Pakistani immigrant. Other songs, too, refer to non-Congolese immigrant groups. In the clip of Gandhi's "L'Orage dans Nos Cerveaux," a couple of Muslim women and their children pass by. Djubay's (2008) title phrase "on me demande" (one asks me) is also articulated by an older convenience shop owner and a young manager of a kebab house, both of foreign origin. In this way, Djubay suggests that these fellow immigrants deal with similar questions. More generally, these performing immigrants reveal that the Congolese identify with particular Brussels districts and all of their inhabitants, not with Belgium or the Congo.

So far, Congolese hip-hop does not fundamentally differ from international hip-hop. Poverty, violence, hopelessness, and segregation all are recurrent elements characterizing the genre. The same applies to the importance of local neighborhoods. Tricia Rose (1994) argues 
that "rap videos themes have repeatedly converged around depiction of the local neighborhood and local posse, crew, or support system." Other authors working on European countries have confirmed this (Helenon 2006, 157). Just as ghettos in the U.S. were a source of authenticity, Congolese pay much significance to their quartiers chauds (hot districts). Abou Mehdi (and A. K. I. 2011) even literally sings, "Je suis né dans le ghetto" (I was born in the ghetto). Apart from the specific Brussels context, the main difference with American and other hip-hop must therefore be found in the (post-) colonial theme.

\section{THE CONGO CONTEXT}

Along with the urban context, most Congolese hip-hop artists sing about the motherland. Many of them denounce the situation in the Congo. Famine and poverty are deplored, for instance, in the lyrics, "La terre est riche, les gens pauvres, il y a un truc faussé" (The earth is rich, people are poor, something is distorted) (HB et al. 2010). Other recurrent issues relate to warfare: "La guerre aime le Congo, car elle est négrophile." (Being negrophile, war loves the Congo.) (ibid.) 13Hor and Djubay (2010), as well as Gandhi (2010a), devoted songs to child soldiers or "kadogo." Baloji (2007e) raps: "Ton fils, un assassin au regard de brais qui a treize ans, trouve son assurance dans un M16." (Your son, a murderer looking like somebody of thirteen years old, finds his security in an M16.)

Most frequently, others are blamed for these tragedies. On the one hand, neighboring countries are held responsible for the violent conflicts: "Les guerres ethniques renforcent le statu quo. Le Congo est un terrain de stratégo, pour ces pays voisins devenus rivaux." (Ethnic wars strengthen the status quo. Congo is a field of strategy for its neighboring countries having become rivals.) (ibid.) On the other hand, the Belgian colonizer is blamed of having sown the seeds of the contemporary social and economic calamities.

When it comes to the colonial era, Congolese hip-hop artists especially highlight the earliest years of colonization: Leopold II's free state (1885-1908). More particularly, they denounce the contrast between the tremendous profits from rubber plantations and the abundance of casualties: "Vingt millions de Congolais sont mort pour les diamants, le zinc, le caoutchouc, pire qu'Hitler et les Allemands" (Twenty million Congolese died for diamonds, zinc, rubber, worse 
than Hitler and the Germans), Abou Mehdi (2011b) wrote on his Facebook wall. "Le caoutchouc, rendrait-il fou? Est-ce que le cuivre drogue ou enivre? Richesses pillées au nom d'le souveraineté" (Did rubber drive people mad? Does copper intoxicate or stun? Wealth looted on behalf of sovereignty), Stefy Rika (and Miskina 2010) sings. Two video clips are recorded at the foot of Leopold II's equestrian statue near the Royal Palace in Brussels (Djubay 2008; Pitcho 2006). Truly, this also reflects the lack of postcolonial monuments in Belgium, neither of the two songs dealing with the Belgian king. Another video clip is shot at the Royal Museum for Central Africa and shows a classroom of Congolese children. All of a sudden, the light goes out, the scared children hide under their school desks, and a white man with black knee-high boots enters the room. Resemblance to Henry Morton Stanley, the explorer of the Congo and servant of Leopold II, cannot be denied (Rika and Miskina 2010).

Other hip-hop artists link the colonial era with its impact on the contemporary Congo. Pitcho (2010e) waits for the return of good luck ("Avec les colonies on a perdu dans l'échange et on attend le retour de la chance" [With the colonies we have lost in the exchange and we are now waiting for the return of good luck]). Baloji (2007e) suggests that the colonial patterns have not yet disappeared: "Reproduire les schémas coloniaux, le pillage de nos minéraux, de nos lingots." (Copy the colonial schedules, the theft of our minerals, of our ingots.) Several hip-hop artists demand the repayment of colonial profits. Not only is Belgium a friend of long debt ("un ami de longue dette" [Pitcho et al. 2010]), even Europe has great debt to Africa ("l'Europe envers l'Afrique maintient une grosse dète [sic]" [HB 2010]). Congo is independent and free, but it needs to rebuild a country and therefore ought to be assisted by its former metropole ("libre mais tout est à reconstruire" [Rika and Miskina 2010]).

The West's contemporary Africa policy is also targeted. Whites continue to interfere in local politics, their paternalism and feelings of superiority not yet having waned. "Je rejette l'homme blanc, son mouvement Réformateur qui veut récupérer l'Afrique comme Tintin l'explorateur." (I reject the white, his Reformatist movement that wants to claim Africa as did Tintin the explorer.) (Banza 2010) Even NGOs are not spared from indictment: "des ONG depuis des décennies" (NGOs for decades) (Gandhi 2010d). In several hip-hop artists' eyes, they enhance Congolese dependence on Europe, for a giving hand is a directing hand ("main qui donne, main qui dirige" [Baloji 2007e]). 
Baloji (ibid.) therefore favors "des petites, moyennes entreprises qui ne connaissent pas la crise. La crédulité des gens en guise de budget, ils investissent là où s'arrêtent les ONG" (small and medium-sized companies who are not touched by the crisis. The credulity of people by means of the budget which they invest there where the NGOs stop). His colleague Pitcho featured in an advertisement of the Belgian development organization Trias (n.d.), which supports people working in smallholder agriculture or as micro-entrepreneurs. In the advertisement, he prepares for a date, but his neighbor puts on his tie, the florist chooses the bouquet (a cactus), and the waiter chooses his dinner.

This is not to say that Congolese hip-hoppers only blame the Belgians. On the contrary, they also frequently point at Congolese responsibility. Pitcho (2010c) is quite clear about this: "Le problème c'est nous, la solution c'est nous, c'est nous contre tous, trop Mobutu entre nous, peu de Mandela parmi nous." (We are the problem, we are the solution, it is us against all, too much of Mobutu between us, too little of Mandela amidst us.) BD Banx (and Massamba 2010) raps that "le plus grand ennemi du Congo reste le Congolais" (the Congolese are the biggest enemies of the Congo). The country should instead take its future in its own hands: "Trop longtemps qu'on nous assiste. Longtemps qu'on reste assis. Qu'on met tout sur les racistes." (We've been assisted for too long. We've remained seated for too long. We've blamed the racists for everything.) (Pitcho 2010c) If the Congo fails to do so, its children will leave: "Je me suis demandé comment une nation peut-elle rêver d'avenir quand elle maltraite sa jeunesse? Comment peut-elle encore s'étonner de voir ses enfants s'éloigner ainsi de la genèse?" (I wondered how a nation can dream of a future when it maltreats its youth? How can it be surprised when it sees how children turn away from their genesis?) (Kaba 2010)

Both the Congolese population and its leaders are guilty of the deadlocked development. A number of hip-hoppers even make use of colonial stereotypes while accusing their compatriots: "Même si on bouffe peu, on adore faire la sièste. Chez nous on dort depuis des siècles." (Even when we eat little, we love to have a siesta. We have been sleeping for centuries.) (Pitcho 2010c) Baloji (2007e) thinks that the country is worse off than in its darkest colonial years under Leopold II: “C'est pire qu'au temps de Léopold." (It is worse than in the time of Leopold.) For most of them, this is the fault of the new political class: "des présidents qui s'en mettent plein les poches" (presidents who fill 
their pockets) according to Gandhi (2010d), or "des pantins" (clowns) in Mayele's (HB et al. 2010) words.

The only Congolese leader who deserves respect is Patrice Lumumba (Gerard and Kuklick, forthcoming). He is featured in many songs and in different ways. Several authors refer to his stunning speech at the celebration of the Congolese independence on 30 June 1960, in which Lumumba strongly criticized the Belgian colonial rule and used the opposite narrative of King Baudoin's speech. Abou Mehdi (2007) used it for lyrics, 13Hor (2010a) turned the whole speech into a song, and Dalsim (2009) integrated pictures of the event in a video clip. Another iconic scene returns in a clip of $\mathrm{Za}$ (2009): a violent arrest of Lumumba during which he is beaten by the Congolese police "Force Publique."

Lumumba is a highly contested figure, also among Congolese, ${ }^{4}$ but in a study on the imagination of Lumumba in urban art in the Congo, Bogumil Jewsiewicki $(1999,27)$ argues that the symbol of Lumumba has been translated to contemporary contexts and that he is depicted as, for instance, a Moses or a Jesus. The same applies to his representation by Congolese hip-hop artists in Belgium. Lumumba is often put in a modern context. A number of artists complain about the fact that he is ignored in Belgium. Baloji (2007e) calls on people to wear t-shirts with a print of his face "en t-shirt à l'effigie de Lumumba pour leur faire oublier le Che" (in a t-shirt with the image of Lumumba in order to make them forget Che Guevara). Banza Kasa Vubu (2010) demands a new inquiry into the circumstances of Lumumba's assassination. The early 2000s parliamentary commission's conclusion did not go far enough for many. A major criticism was that Congolese have not been involved in the inquiry (Ceuppens 2007). Congolese hip-hop artists have therefore not yet come to terms with his death. Pitcho (and Massamba 2010) is very explicit about this: "Je continue le combat et toute la force est dans le courage de l'héritage de Lumumba." (I continue the fight and all the strength is in the courage of Lumumba's heritage.)

Patrice Lumumba is put on the same level with other champions of the black movement. The cover of Pitcho's CD Crise de Nègre (2010a) depicts portraits of Malcolm X, Martin Luther King, Nelson Mandela, Spike Lee, Josephine Baker, Louis Armstrong, Bob Marley, and Barack Obama. Abou Mehdi starts his "Intifada" clip with a fragment of a show in which he lists his major examples: Gandhi, Lumumba, Malcolm X, Ayatollah Khomeini, Muhammad Ali, and 
Che Guevara. Apart from Lumumba, none of them are Congolese. Djubay (2008) regrets the lack of native heroes: "Pourquoi' il n'y a plus des héros comme Patrice Lumumba?" (Why are there no more heroes like Lumumba?) The only other figure that is related to the Congo is Muhammad Ali, the boxing champion who opposed the Vietnam War ("No Vietcong ever called me nigger"). Ali defeated world champion George Foreman in a legendary fight in Kinshasa on 30 October 1974. This "rumble in the jungle" is one of the glorious events that put the Congo on the world map in a positive way, and gratifies the pride of contemporary hip-hop artists. Particularly Za's "Bomaye" (2009) refers to boxing. The clip shows many pictures of the boxers and the title is one of the slogans Ali was cheered with: "Ali bomaye," which means "Ali, smack him."

\section{NEGLECTED VOICES?}

It is clear that the Congolese hip-hop artists'knowledge of their country of origin is limited. They chiefly make use of symbols. Nicknames such as Gandhi refer to heroes of decolonization. Calamities are symbolized with the most common icons, such as the baton's blow and the child soldier. The colonizer is personalized by means of the bestknown protagonists, both real (Leopold II and Stanley) and fictitious (Tarzan and Tintin). Congolese freedom is only epitomized by Lumumba. Other resistance fighters, such as the revolutionary Pierre Mulele (1929-1968), the human rights activist Floribert Chebeya (1963-2010), and even the former president Laurent-Désiré Kabila (1939-2001) never show up in songs. Of course, these individuals are subject to fierce debates, and none of them is unanimously accepted as a champion of the Congolese nation. But the same applies to Lumumba.

Hip-hop artists are aware of this modest acquaintance with the Congo. Baloji (2007c) confided in an interview that he knew as little about the Congo as his interlocutor. But he was also very open about it in a song (Baloji 2007a): "J'en ai oublié mon pays et ma langue." (I forgot my country and my tongue.) Their ignorance is not surprising since most of them left the Congo at an early age or were born in Belgium. Both Pitcho (born in Kinshasa in 1975) and Baloji (born in Lubumbashi in 1978) fled the country when they were four. Their fathers had clashed with Mobutu and immigrated with their families 
to Belgium. Abou Mehdi, 13Hor, and Djubay were also born in the Congo and settled in Brussels in the late 1980s or the early 1990s. Gandhi was born in a Paris banlieue (suburb) and moved to Belgium in 1992. Other rappers, such as Za, Dalsim, and Romana, were born in Belgium. ${ }^{5}$ Most of the Congolese have never returned to their homeland.

They therefore rely on secondary sources to obtain information about the Congo. However, they are not satisfied with them. Their parents, for instance, have not shared many past experiences with their children. "Les langues se coupent lorsqu'on parle du passé. Nos anciens deviennent muets" (Tongues are cut off when we talk about the past. Our elderly become mute), sings 13 Hor (and Kankonda 2010). Stefi Rika (and Miskina 2010) is even more explicit: "Mon histoire c'est pas maman qui me l'a contée. J'ai vu mon héritage exposé dans un muse." (It is not my mum who told me my history. I saw my heritage on display in a museum.) Some hip-hop artists understand their parents' situation and realize that their emigration experience was a big shock. Gandhi (2010g), for instance, sings about his father's social decline: "Je me souviens de sa Mercédès, je me souviens de sa Porche, je me souviens que la propriétaire l'appelait boss. Les années passent et on quitte notre bel appart pour un flat. Papa n'a plus de voiture allemande mais un flat." (I remember his Mercedes, I remember his Porche, I remember that the landlord called him boss. The years have gone by and we left our beautiful apartment for a flat. Daddy does not have a German car any longer but a flat.) Yet, this understanding goes together with criticism. The second generation blames the parents for being too positive about colonization. Having grown up in the colonial era, they still show respect for their white uncles: "Eux ont gardé l'accent appellant les blancs buana." (They kept their accent and called the white buana.) (BD Banx and Massamba 2010) This impedes them from coming to terms with their own experiences: "Le silence de nos parents est éloquent. Pour eux depuis longtemps le modèle était le blanc." (Our parents' silence is telling. For a long time, white has been their model.) (Pitcho 2010b) Apparently, the gap between the two generations is huge: "Nos parents ne comprennent pas, par example que l'on critique le colonialisme... Mais nous, on veut comprendre." (Our parents do not understand why we criticize colonialism. But we, we want to understand.) (Pitcho quoted in Jarry 2006, 7) However, this is not very surprising. Generation conflicts and heteropraxis-i.e., the unevenness and the different paces of the process of social and 
cultural changes-frequently occur with migrants (Lesthaeghe 2000, 27).

Next to parents, Belgium as a host society is also blamed for neglecting the Congolese past. Belgian education programs do not pay much attention to the colony: "J'ai passé mon enfance en Belgique et en classe masta... rarement entendu les crasses du roi." (I spent my childhood in Belgium and in class ... rarely heard of the king's dirt.) (13Hor and Djubay 2010) On the contrary, the Congolese have to adapt to the narratives of the Belgian majority and are taught a past they can hardly identify with: "Quand j'ai appris l'adolescent ce qui sétait passé au Congo, je me suis révolté en classe car j'en avais marre d'entendre au cours d'histoire: 'mes ancêtres sont les Gaulois."'(When I learned as a teenager what had happened in the past to the Congo, I revolted in school since I was tired of hearing in history class that the Gauls are our ancestors.) (Pitcho quoted in Jarry 2006, 7)

The criticism of Belgium exceeds education programs. Congolese are uncomfortable about the way they are dealt with in Belgian society as a whole. Either they are given the cold shoulder: "Ignoring me, and diggin' me in the ground," as Senso (Pitcho et al. 2010) raps; or they are referred to the complexity of Belgium's colonial past: "D'où nous vient ce complexe? Quand on parle de nous, tout devient complexe." (Where does this complex come from? When one talks about us, everything gets complex.) (Pitcho 2010b) As a consequence, the Congolese do not feel recognized. Their traumas are still existent: "Le fantôme de Léopold est toujours dans nos têtes.” (Leopold's phantom is always in our heads.) (Pitcho and Massamba 2010) However, they have to deal with them alone. Jack (Pitcho et al. 2010) juxtaposes the Belgian and the Congolese memory of the colonial past: "Viols, massacres, fierté bafouée, chez toi c'est du passé, or que les miens nont pas cicatrisés." (Rapes, massacres, ridiculed proud: it belongs to the past for you, but we haven't healed this yet.) Pitcho (2006) realizes that it will take time and energy for the Congolese to come to terms with their traumas and that a Belgian helping hand may be useful: "Faudrait qu'on tourne la page mais on n'a pas fini d'écrire. Ca sera pas fini tant que des cris viendront accompagnés des pleures." (We should turn the page, but we have not finished writing it. It will be over when cries will come together with tears.) HB (et al. 2010), too, hopes that he will find a listening ear in Belgium: "Je rêve que la politique soit à l'écoute des enfants de la république." (I hope that politics will listen to the children of the republic.) 
His dream has partly become true. In 2010, the Royal Museum for Central Africa (Tervuren, near Brussels) launched the Héritage project as part of the celebrations of the fiftieth anniversary of Congolese independence. It invited Congolese artists in Belgium in order to reflect on their colonial past and to voice this in new songs. For many hip-hop artists, the inaugural meeting in Tervuren in January 2010 was their first encounter with the museum. More than twenty artists were involved with the project. Together, they registered an album and held a couple of concerts, which were organized with other venues in Brussels. The launching concert took place on 30 May 30 2010, at Bozar (Palais des Beaux-Arts, or the Center for Fine Arts) in Brussels, which was having a festival called Visionary Africa. A week later, on 6 June, Pitcho and Freddy Massamba played the song "Enfant du Pays" at a concert organized by Belga-Vox, a non-profit organization that aims at enforcing the Belgian identity as well as multicultural dialogue and solidarity. A second Héritage concert was held on 11 December. In May 2011, the Héritage collective performed twice: at the socialist Labor Day observance on 1 May, and at the Africa-Tervuren Festival on 15 May (Pitcho 2011).

The Héritage project was organized by Belgian institutions but was initiated by the Congolese. It was Pitcho who had come up with this idea and had contacted the Royal Museum for Central Africa in January 2009. The project was approved of by the Belgian side, but not by all Congolese hip-hop artists. Some of them—such as $\mathrm{Za}$, Dalsim, and Abou Mehdi-did not participate since they thought that this clashed with their urban and underground profile.

Nevertheless, the project was a landmark for the Congolese in Belgium and their dealing with the colonial past. Prior to 2009, Congo had been a far less important issue in their songs. Baloji was one of the single hip-hop artists who had shown interest in his country of origin before that year. In 2007, he released the album Hotel Impala, named after the hotel that his father ran but lost by looting when Baloji was four years old, an event that led to his emigration to Belgium. Baloji went back to the Congo and wrote a number of songs about his complicated relationship with his ancestors' land. At the time, he was an exception. Most of his fellow artists began singing about post-colonial issues from 2010 onwards. The fiftieth anniversary and, particularly, the Héritage project was a pivotal incentive.

The Tervuren interest was not entirely shared by the rest of the country. As a matter of fact, the project's reception varied within 
Belgium. The French-speaking part paid some attention. Radio stations in Brussels and Wallonia-such as NRJ, RTBF Pure FM, FM Brussel, RTBF La Première, and Radio KIF-broadcasted songs as well as interviews with their performers. Several television channelsincluding Télé Bruxelles, RTBF La Deux, and Arte-provided commentary. More than twenty articles on the project can be found in Brussels and Walloon newspapers, such as Le Soir, La Libre Belgique, Le Vif l'Express, and La Tribune de Bruxelles.

The northern, Dutch-speaking part of Belgium, by contrast, was much more silent about the Héritage events. Only one newspaper covered the event, De Standaard, publishing an interview with Pitcho but incorrectly illustrating this with a picture of Freddy Massamba (Tollet 2010). ${ }^{6}$ Only one channel, the elite and less popular Canvas, reported on the project in the cultural program Cobra TV. Only one radio station, Radio 1 , made mention of Héritage, but failed to play music from the album. ${ }^{7}$ This is not completely surprising, since the songs are in French and less accessible to a Flemish audience. However, the consequence of this is that in the Flemish part of Belgium, the Congolese voice remains silenced.

\section{CONCLUSION: HYBRID IDENTITIES AND POSTCOLONIAL CRITICISM}

It is clear that Belgians associate with the Congolese and their memory of the past in an inappropriate way. Congolese hip-hop songs show that there is a great deal of criticism of the colonial era and frustration about the way this is dealt with today. There is neither gratitude nor nostalgia, sourire nor joie de vivre. On the contrary, several songs express firmness and combativeness. Pitcho (2010d), the pioneer of the Héritage project, is quietly militant: "Ne dis pas que je n'ai pas prévenu, militant alors je me bats." (Do not say that I have not warned you, I am militant, so I will fight.) In another song (2006), he even suggests revenge: "J'reste les bras en l'air et le poing serré... Pour les têtes tombées et les mains coupées. Pour nos tribus enchainées et nos peuples à serrer. Pour nos pères lynchés et nos familles exilés. Pour nos mères souillées et nos terres dépouillées. Pour le sang versé, pour les larmes quon a coulées. Pour nos richesses volées et nos sœurs violées. Pour nos ethnies humiliées décimées par millier. Pour nos gosses désherités, nos héros assassinés." (I keep my arms in the air 
and my fist clenched. For the fallen heads and the cut hands. For our chained tribes and our repressed peoples. For our lynched fathers and exiled families. For our soiled mothers and our deprived lands. For the bloodshed and the tears cried. For our stolen riches and our raped sisters. For our humiliated ethnicities, decimated by thousands. For our disinherited kids, our assassinated heroes.) His music is an obvious way of release, through which he can ventilate his feelings. Baloji (2007d), too, struggles with this: "J'ai chialé comme un môme, ça m'a aidé à mettre des noms sur ces fantômes qui me hantent et me tourmentent." (I've been blubbering as a kid, but this helped me in naming the phantoms that haunt and torment me.)

Hip-hop is indeed a way of searching for an identity. The hip-hop artists deal with what Homi Bhabha has labeled hybridity. They feel several identities which are not always compatible and are difficult to give a proper place. Pitcho (2010b) labels this a crise de nègre and has named his album after this: "Dans tout ce bordel je cherche ma place. Je n'arrive pas à la trouver et ça me tracasse. Au bord de la crise de nerves, j'ai développé une crise de nègre." (I have been looking for my place in this brothel. I cannot find it and this bothers me. On the verge of a nervous breakdown, I developed a negro's breakdown.) In addition, the music and lyrics of the artists keep going a dialectic of the pedagogic and the poetic which according to Bhabha is so characteristic of post-colonial hybrid consciousness (cf. Huddart 2007). The language of nation and abstract rights is present, but it is subjected to a hybridizing process, effectuating shifts in meaning. The legacy of Lumumba is praised, but the political leader is enlisted in a chain of personal heroes of various professions and provenance. Hinted as solutions to Congolese problems, the modalities of education and liberal entrepreneurialism are modified to make room for subaltern practices. Popular music, hip-hop's vehicle of choice, is likewise a product of cultural hybridization. Drawing on a manipulation of sounds, its performative style intimates basic acts of cognition which are easily translated across the "frontiers of contiguity" of self-defined cultures (Kapferer and Hobart 2005, 16-17). ${ }^{8}$

But the artists are also searching for figurative ways to express their fractured sense of belonging. Gandhi (2010b) compares it with a game of dice, in which the dice is covered with his different identities: a black immigrant, a Belgian, a Congolese, an urban hip-hop artist, an inhabitant of a French banlieue (where he was born), and a local of a Brussels quartier chaud (red-light district). On the cover of his Crise de 
Nègre album, Pitcho uses the image of a hat: an attribute about which you can decide whether you put it on or not, but which you ought to take off in certain situations. The hat thus also symbolizes the fact that you do not control your entire identity. A third metaphor is the pigiphant, a merger of a pigeon and an elephant. The pigeon is both a northern and an urban animal, while the elephant symbolizes Africa as well as the weight of the Congolese heritage (Remy 2010; Tollet 2010; Ceuppens, forthcoming).

Through the metaphors of bounties, dice, hats and pigiphants, the Congolese performers in Brussels give expression to a "poetic individualism" (borrowed from Huddart 2007, 28) which cannot be reduced to the categories of an abstract universalism. They steadfastly refuse to strip these attributes from the very essence of their being. For a long time in Belgium, contributions such as these have been all too easily ignored for their lack of academic rigor. Today, the Héritage project seems like a first step to recognize the problem and de-center the dominant perspective on the colonial past. For some, the project was conceived as a plea for reconciliation on multiple levels. In an interview, Pitcho (quoted in Tollet 2010) makes a reference to hybridity and calls to accept it: "Het is tijd dat we onszelf aanvaarden om wat we zijn: hybriden. Dat is noch een nadeel, noch een voordeel. Het is gewoon wat we zijn." (It is time for us to accept that we are hybrids. This is neither a burden nor a benefit. It is just what we are.) Others, however, do not see things quite the same way. Cecilia Kankonda and 13Hor (2010) wrote a text for the project, in which they are critical: "Héritage, oh héritage, héritage... Inventé par la race des sages pour ne pas nous permettre d'oublier que nous sommes pour toujours lies à notre passé sur lequel il ne sert en général à rien de s'attarder." (Heritage, oh heritage, heritage. . Invented by the race of sages in order to prevent us from forgetting that we are always linked to our past on which we should not linger.) Arguing that the project does not help them come to terms with their past, they keep struggling with feelings of being uprooted, being in-between, instability, and uncertainty.

It is clear that Congolese hip-hop artists are struggling with the colonial past. Obviously, their situation is very specific, being colored by their generation, their immigration to Belgium, and the urban culture they are embedded in. Similarities and differences can be noted with the situation in France. In this neighboring country, postcolonial hip-hoppers devote many songs to the colonial legacy, accounting for their personal as well as their peoples' situation, without neglecting 
the proper African responsibility. However, as scholars have argued, "they assertively define their own hybridized identity as French" and in doing so, "are pushing for a redefinition of what it means to be French” (Darling-Wolf 2008, 200; cf. Helenon 2006; Huq 2001; Schumann 2011). Such claims are less explicit among Congolese rappers in Belgium and suggest a larger gap with the majoritarian Belgian cultures.

The language of the postcolonial hip-hop scene is indeed at odds with the mainstream discourse on the Belgian colonial past. With their criticism steeped in the poetic, the hip-hoppers are also much fiercer than the Congolese historians who dominate the narrative with their pen. Although their grasp of historical topics has recently expanded from exposure to the pedagogic thrust of the Tervuren Museum, the artists do not possess an encyclopedic knowledge of the Belgo-Congolese history. Given their present purposes, however, such criticism would be entirely beside the point. While the performers may debate about the exact meaning of Héritage, their goal is never to simply replace the dominant discourse. The logic of their enunciations seems to revolt against the idea of a finite past whose record merely needs to strike the right balance. Resisting an exercise of facile multiculturalism, the idea is not so much to let the past rest as a precondition for present harmony, but to keep the past close by as a reminder of the unfinished moment of the present.

\section{NOTES}

On Isidore Ndaywel è Nziem, see Goddeeris and Sindani 2011.

2 See Ceuppens 2004. The author now works on mulattos in Belgium, a subject that has also been researched by Lissia Jeurissen (2004, 40-42).

3 The empirical research was conducted by Jamina Mertens, who wrote a M.A. thesis about the subject. Wouter Goedertier was the main supervisor of this work, and Idesbald Goddeeris turned the thesis into an article. Dominique De Brabanter assisted with the revision of the article following the review process.

4 See the ongoing research by Katrien Pype (MIT and Leuven University), Pedro Monaville (University of Michigan), and Isabelle de Rezende (University of Michigan), who held a session on the Congolese memory and representation of Lumumba at the 54th Annual Meeting of the African Studies Association (Washington, 17-19 November 2011). Daniel Toedt (Humboldt University, Berlin) is also working on this topic.

5 Information obtained through communication with the artists (e-mail, facebook, and interviews).

6 Next to this, the monthly Mo* Magazine also paid attention to Congolese migration and hip-hoppers in Belgium (Jun. 2010). However, again, there were more Frenchlanguage magazines doing so (e.g., Imagine Demain Le Monde [Jul.-Aug. 2010] and CBAl [Jun. 2010]). 


\section{REFERENCES}

13Hor. 2010a. 1960: Gravé dans nos coeurs. In 13Hor 2010 b.

---. 2010b. Cris du cœur. BLV.

13 Hor and Cecilia Kankonda. Héritage. In Various artists 2010.

13Hor and Djubay. 2010. Kadogo. In Various artists 2010.

Abernethy, David. 2000. The dynamics of global dominance: European overseas empires 1415-1980. New Haven: Yale University Press.

Baloji. 2007a. Entre les lignes. In Baloji 2007b. Online, http://www.youtube.com/watch ? $v=$ ZMJT85scgFI, accessed 19 Oct. 2011.

---. 2007b. Hotel Impala. EMI France.

---. 2007c. Ostende Transit. In Baloji 2007b. Online, http://www.youtube.com/watch ? $\vee=c V b d j g I m j N Q$, accessed 19 Oct. 2011.

---. 2007d. Septembre. In Baloji 2007b. Online, http://www.youtube.com/watch ?v=BrmxfLWychO, accessed 19 Oct. 2011.

-- - 2007e. Tout ceci ne vous rendra pas le Congo. In Baloji 2007b. Online, http://www .youtube.com/watch?v=WNoFpT5jOQM, 19 accessed Oct. 2011.

--_. 2011. Kinshasa succursale. Crammed Discs.

Bancel, Nicolas, Florence Bernault, Pascal Blanchard, Ahmed Boubeker, Achille Mbembe, and Françoise Vergès, eds. 2010. Ruptures postcoloniales: Les nouveaux visages de la société française. Paris: La Découverte.

Banza. 2010. Contre-expertise. In Various artists 2010.

Basu, Dipannita and Sidney Lemelle, eds. 2006. The vinyl ain't final: Hip hop and the globalization of black popular culture. London: Pluto Press.

BD Banx and Fredy Massamba. 2010. Muana Poto. In Various artists 2010.

Beau, Marie-Agnès. 1996. Hip-hop and rap in Europe: The culture of the urban ghetto's. In European Music Office, Music in Europe II: Music, culture and society in Europe, ed. Paul Rutten, 129-34. Brussels: European Music Office.

Bertrand, Romain. 2006. Mémoires d'empire: La controverse autour du "fait postcolonial". Bellecombe-en-Bauges: Editions du Croquant.

Bhabha, Homi K. 1985. Signs taken for wonders: Questions of ambivalence and authority under a tree outside Delhi, May 1817. Critical Inquiry 12: 144-65.

Butlin, Robin A. 2009. Geographies of empire: European empires and colonies c. 18801960. Cambridge: Cambridge University Press.

Castryck, Geert. 2006. Whose history is history? Singularities and dualities of the public debate on Belgian colonialism. In Europe and the World in European Historiography, ed. Lévai Csaba, 71-88. Pisa: PLUS-Pisa University Press.

2007. Lumumba: De complotten? De moord: Onderzoeksrapport of historische studie? Bijdragen en Mededelingen betreffende de geschiedenis der Nederlanden 122: $385-400$.

- - Forthcoming. Créer sa propre monde? Les jeunes Congolais en RDC et en Belgique: Conflits intergénérationnels. In L'indépendance du Congo et ses lendemains dans quelques regards du XXle siècle: Réflexions, historiographie, mémoires, représentations, collections, ed. Bambi Ceuppens and Sabine Cornelis. Tervuren: KMMA. 
Corin, Ben and Sarah Vankersschaever. 2012. 'Vlaamse hiphop? Sorry, niet goed genoeg' Vlaamse hiphoppers kunnen niet tippen aan het succes van DE Nederlandse hiphop. De Standaard, 7 Feb.

Daking, Romano. 2010. Carrefour de ma vie. Online, http://www.youtube.com/watch ?v=KqOujnbzpNA, accessed 19 Oct. 2011.

Dalsim. 2009. L'art du bitume. Online, http://www.youtube.com/watch?v=pauc6cBJnes, accessed 19 Oct. 2011.

---. 2010. Nitro. Online, http://www.youtube.com/watch?v=kjV2LjoRI6I, accessed 19 Oct. 2011.

Darling-Wolf, Fabienne. 2008. Getting over our "illustion d'optique": From globalization to mondialisation (through French rap). Communication theory 18: 187-209.

De Vos, Luc, Emmanuel Gerard, Philippe Raxhon, and Jules Gérard-Libois. 2004. Lumumba: De complotten? De moord. Leuven: Davidsfonds.

De Witte, Ludo. 1999. De moord op Lumumba. Leuven: Van Halewyck.

--- 2001. The assassination of Lumumba. London: Verso.

Djubay.2008. On me demande. Online, http://www.youtube.com/watch?v=owtZmaCZD1c, accessed 19 Oct. 2011.

Durand, Alain-Philippe. 2002. Black, blanc, beur: Rap music and hip-hop culture in the francophone world. Lanham: Scarecrow Press.

Etambala, Zana Aziza. 1993. In het land van de Banoko: De geschiedenis van de Kongolese / Zaïrese aanwezigheid in België van 1885 tot heden. Leuven: K. U. Leuven, Hoger instituut voor de arbeid.

Fanon, Frantz. 1952. Black skin, white masks: The experiences of a black man in a white world. Paris: Éditions du Seuil.

Gandhi. 2010a. J'ai 13 ans. In Gandhi 2010e. Online, http://www.youtube.com/watch ?V=J40_XYOPr78, accessed 19 Oct. 2011.

---. 2010b. Jeux de Maux. In Gandhi 2010a. Online, http://www.youtube.com/watch ?v=z_twVS39DGA, accessed 19 Oct. 2011.

---.2010c.L'EffetBouledeNeige.InGandhi2010e.Online,http://www.youtube.com/watch ?V=m9JSOzoPXYY, accessed 19 Oct. 2011.

- - .2010d. Le monde entier sait. In Gandhi 2010a. Online, http://www.youtube.com/watch ?v=iGTtIpmEmJ8, accessed 19 Oct. 2011.

---. 2010e. Le point G - Tome 1: Jeux de maux. Skinfama.

-- . 2010f. Les bras ballant. Online, http://www.youtube.com/watch?v=NAB1DQ8wRBA, accessed 19 Oct. 2011

---. 2010g. Péripéties. In Gandhi 2010e. Online, http://www.youtube.com/watch ? $v=$ sffL $q$ hVX6yY, accessed 19 Oct. 2011.

Gerard, Emmanuel and Bruce Kuklick. Forthcoming. Death in the Congo: Murdering Patrice Lumumba. Cambridge MA: Harvard University Press.

Gérard-Libois, Jules, Jean Kestergat, Jacques Vanderlinden, Benoît Verhaegen, Jean-Claude Willame, and Colette Braeckman. 2010. Congo 1960: Echec d'une decolonization. Brussels: Grip.

Goddeeris, Idesbald. 2011. Congo in onze navel: De omgang met het koloniale verleden in België en zijn buurlanden. Ons erfdeel 54.1: 40-49.

Goddeeris, Idesbald and Kiangu Sindani. 2011. Congomania in academia: Recent historical research on the Belgian colonial past. BMGN - Low Countries Historical Review 126.4: 54-74.

Goldberg, David Theo. 2009. The threat of race: Reflections on racial neoliberalism. Malden, MA: Blackwell Publishing.

HB. 2010. Pensée j'voudrais qu'il sache tout. Received from the artist, 16 Dec.

HB, Mayele, and Masta Pi. 2010. Tous résisants. In Various artists 2010. 
Helenon, Veronique. 2006. Africa on their mind: Rap, blackness, and citizenship in France. In The Vinyl Ain't Final: Hip hop and the globalization of black popular culture, ed. Sidney Lemelle and Dipanita Basu, 151-66. London: Pluto Press.

Hochschild, Adam. 1999. King Leopold's ghost: a story of greed, terror, and heroism in Colonial Africa. Boston: Houghton Mifflin Co.

Huddart, David. 2007. Hybridity and cultural rights: Inventing global citizenship. In Reconstructing hybridity: Post-colonial studies in transition, ed. Joel Kuortti and Jopi Nyman, 21-41. Amsterdam: Rodopi.

Huq, Rupa. 2001. Rap à la Française: Hip-hop as youth culture in contemporary postcolonial France. In Transitions of youth citizenship in Europe: Culture, subculture and identity, ed. Andy Furlong and Irena Guidikova, 41-60. Strasbourg: Council of Europe Publishing.

Jarry, Frédéric. 2006. Pitcho: La cerise sur le ghetto. ZoneO2, 18 Apr.

Jeurissen, Lissia. 2004. Entre Kinshasa et Bruxelles, les enfants oubliés de la colonization. Politique: Revue de débats 35: 40-42.

Jewsiewicki, Bogumil. 1999. A Congo chronicle: Patrice Lumumba in urban art. New York: Museum for African Art.

Kaba, Angelique. 2010. Sur le boulevard du 30 Juin. In Various artists 2010.

Kagne, Bonaventure. 2008. Africains de la Belgique, de l'indigène à l'immigré. Revue hommes et migrations 1228: 62-67.

Kapferer, Bruce and Angela Hobart, eds. 2005. Aesthetics in performance: Formations of symbolic construction and experience. New York: Berghahn.

Kuppens, An. 2008. De globalisering van hip-hop: Vlaamse hip-hop artiesten over authenticiteit. In Media/Cultuur/Identiteit: Actueel onderzoek naar media en maatschapij, ed. Hilde Van den Bulck and Alexander Dhoest, 37-50. Gent: Academia Press.

Lapiower, Alain. 1997. Total respect: La génération hip-hop en Belgique. Brussels: Vie Ouvrière.

Lesthaeghe, Ron, ed. 2000. Communities and generations: Turkish and Moroccan populations in Belgium. Brussels: CBGS-Publications.

Loh, Hannes and Sascha Verlan. 2000. 20 jahre hiphop in Deutschland. Höfen: Hannibal Verlag.

---. 2006. 25 jahre hiphop in Deutschland. Höfen: Hannibal Verlag.

Maxwell, lan. 2003. Hip hop down under comin' upper: Phat beats, dope rhymes. Middletown: Wesleyan University Press.

Mehdi, Abou. 2007. Je suis. Online, http://www.youtube.com/watch?v=iZPosGC5nkc, accessed 19 Oct. 2011.

---. 2011a. Ca pue la rue. Online, http://www.youtube.com/watch?v=v-EXhjFTsDO, accessed 19 Oct. 2011.

---. 2011b. Facebook message, 21 Mar.

Mehdi, Abou and A.K.I. 2011. Dans le hood. Online, http://www.youtube.com/watch ?v=gLFJRttKWAo, accessed 19 Oct. 2011.

Medhi, Abou and Saladin. 2009. Abou Mehdi et Saladin représentent Charleroi. Online, http://www.youtube.com/watch?v=HJQZusxQ3fk, accessed 19 Oct. 2011.

Mitchell, Tony, ed. 2001. Global noise: Rap and hip-hop outside the USA. Middletown: Wesleyan University Press.

Mucchielli, Laurent. 1999. Le rap, tentative d'expression politique et de mobilisation collective de jeunes des quartiers relégués, Mouvements 3: 60-66.

Nyatanyi, Gilbert. 2007. Symfonie van zwart in wit: Zwarte Afrikanen in België. Brussel: Regionaal Integratiecentrum Foyer Brussel vzW.

Oostindie, Gert. 2010. Postkoloniaal Nederland: Vijfenzestig jaar vergeten, herdenken, verdringen. Amsterdam: Bert Bakker.

Pitcho. 2006. Bras en l'air et le poing serré. Online, http://www.youtube.com/watch ?v=f3yr93RoToQ, accessed 19 Oct. 2011. 
---. 2010a. Crise de nègre. Skinfama.

--- 2010b. Crise de Nègre. In Pitcho 2010a. Online, http://www.youtube.com/watch ? $v=$ ABhH3rjiHUY, 19 accessed Oct. 2011

---. 2010c. Nous. In Pitcho 2010a.

-- . 2010d. On va célébrer. In Pitcho 2010a.

-- 2010 e. Terre de sang. In Pitcho 2010a.

-_- 2010f. Usual Suspect. In Pitcho 2010a.

---. 2011. Héritage-project: Informatie CD-Rom. Tervuren: Royal Museum for Central Africa.

Pitcho and Fredy Massamba. 2010. Enfants du pays. In Pitcho 2010a. Online, http://www .youtube.com/watch?v=TtE2sTIS9z4, accessed 19 Oct. 2011.

Pitcho, Senso, and Jack. 2010. Frères ennemis. In Various artists 2010.

Remy, Céline. 2010. Shake that diaspora. CBAl, Jun.

Rika, Stefy and Nina Miskina. L'Afrique est mon âme. In Various artists 2010. Online, http:// www.youtube.com/watch?v=kNynEnPMagA, accessed 19 Oct. 2011.

Rose, Tricia. 1994. Black noise: Rap music and black culture in contemporary America. Middletown, CT: Wesleyan University Press.

---. 2008. The hip hop wars: What we talk about when we talk about hip hop and why it matters. New York: Basic Civitas.

Schoonvaere, Quentin. n.d. Studie over de Congolese migratie en de impact ervan op de Congolese aanwezigheid in België: Analyse van de voornaamste demografische gegevens. Louvain-la-Neuve: Studiegroep Toegepaste Demografie (UCL) and Centrum voor Gelijkheid van Kansen en voor Racismebestrijding.

Schumann, Adelheid. 2011. Le rap en France; Expression de rage et de violence de la jeunesse black-blanc-beur. In Violences postcoloniales: Représentations littéraires et perceptions médiatiques, ed. Isaac Bazié and Hans-Jürgen Lüsebrink, 315-26. Berlin: Lit Verlag.

Sioen, Lieven. 2010. Baloji - Niet Belgisch, niet Congolees. De Standaard, 4 Apr.

Terkourafi, Marina. 2010. Languages of global hip-hop. London: Continuum International Publishing Group.

Tilkin, Kristoff. 2011. Humo's raprapport: Hiphop in Vlaanderen. Humo, 14 and 21 Nov.

Tipo-Tipo, Mayoyo Bitumba. 1995. Migration sud/nord levier ou obstacle? Les zairois en Belgique. Brussels: Institut africain-CEDAF.

Tollet, Benjamin. 2010. In Afrika hebben we geen visionairs. De Standaard, 28 May.

Trias. n.d. "ONG NGO Trias avec Pitcho Wombakonga." Online, http://www.youtube.com /watch?v=4ibLAE93wcw, accessed 19 Oct. 2011.

Van Cauwelaert, Rik. 2010. Hardnekkig geheugenverlies. Knack, 30 Jun.

Vanden Broucke, Steven. 2006. Hiphop in Vlaanderen. Een sociologische analyse. M.A. thesis, Gent.

Van der Pijl, Kees. 2007. Nomads, empires, states: Modes of foreign relations and political economy. London: Pluto.

Vanmarsenille, Stijn. 2001. Hiphop in Vlaanderen: Een literatuurstudie en een inhoudsanalyse van rapteksten. M.A. thesis, Gent.

Van Reybrouck. David. 2010. Congo: Een geschiedenis. Amsterdam: De Bezige Bij.

Various artists. Héritage. 2010. Skinfama.

Wihtol de Wenden, Catherine. Postcolonialisme et immigration: nouveaux enjeux. In Bancel et al. 2010, 256-64.

Za. 2009. Bomaye. Online, http://www.youtube.com/watch?v=ck96kEpMBjl, accessed 19 Oct. 2011. 
JAMINA MERTENS obtained an M.A. in history at KU Leuven (Belgium) in 2011, with a thesis on Congolese hiphop in Belgium. She now works with the faculty of psychology and pedagogical sciences of the KU Leuven.

WOUTER GOEDERTIER acquired M.A. degrees in social sciences (University of Ghent) and European studies (KU Leuven). He is currently preparing his doctoral dissertation with the History Research Unit of the KU Leuven (Belgium) on Belgian solidarity with the anti-apartheid movement.

IDESBALD GODDEERIS is an associate professor of imperial and transnational history at KU Leuven. His research focuses on Cold War history and on migration history. He has recently published, inter alia, Migrants flamands en Wallonie 1850-2000 (with R. Hermans, ed.; Brussels 2012); Revoluties onder historici (Tielt 2011), and Solidarity with Solidarity: Western European trade unions and the Polish crisis, 1980-1982 (The Harvard Cold War studies book series; Lexington, 2010). <idesbald.goddeeris@arts.kuleuven.be>

DOMINIQUE DE BRABANTER obtained her M.A. in history at KU Leuven in 2011 and now works at the Leuven Centre for Global Governance Studies. 